INTERDISCIPLINARIA ARCHAEOLOGICA NATURAL SCIENCES IN ARCHAEOLOGY

\title{
Morphology and Molecular Analysis of Ancient Grape Seeds
}

\author{
Claudio Milanesi ${ }^{a^{*}}$, Francesca Antonucci ${ }^{b}$, Paolo Menesatti ${ }^{b}$, Corrado Costa $^{\mathrm{b}}$, \\ Claudia Faleria, Mauro Cresti ${ }^{\mathrm{a}}$ \\ aArchaebotany Laboratory, Department Environmental Science "G. Sarfatti”, Via Mattioli 4, 53100 Siena University, Italy \\ ${ }^{b}$ Agricultural Engineering Research Unit of the Agricultural Research Council (CRA-ING), Via della Pascolare 16, 00015, Monterotondo scalo, \\ Rome, Italy
}

\section{ARTICLE INFO}

\section{Article history:}

Received: 5 December 2011

Accepted: 20 December 2011

\section{Key words:}

ancient DNA

archaeological grape seeds

SSRs nuclear Microsatellites

elliptic Fourier analysis (EFA)

tegument tissue

\begin{abstract}
$A B S T R A C T$
The morphometry of Vitis vinifera seeds from different archaeological sites was studied. Preservation status differed between sites. Non-invasive and quantitative image analysis based on elliptic Fourier analysis (EFA) established different morphological variations between populations. Molecular analysis was performed to study genetic relationships, using nuclear microsatellite SSRs markers with high polymorphism. Morphometric analysis of archaeological endocarp outlines and allelic profiles of endocarp tegument delineated the general species-specific qualities of the modern cultivar.
\end{abstract}

\section{Introduction}

Morphometric measurements and quantitative image analysis based on the study of endocarp outline by elliptic Fourier shape analysis discriminates cultivar groups (Mangafa, Kotsakis 1996; Menesatti et al. 2008; Terral et al. 2010).

SSR markers for molecular genetic studies have produced methods for limiting contamination, for designing phylogenetic studies (Sefc et al. 2000), and for obtaining information from tiny quantities of archaeological material (Blatter et al. 2002). SSR markers have high polymorphism and have been used to determine genetic profiles of contemporary varieties of Vitis vinifera (Sefc et al. 1998; Bowers et al. 1999; Vignani et al. 2008).

The aim of the present study is to examine grape seeds from different archaeological sites. An outlines analysis (i.e. elliptic Fourier analysis) was applied to quantify the differences between living cultivars and observe the similarities of the archaeological samples within the morphospace. Molecular studies with cytoplasmic markers were

*Corresponding author, e-mail: claudio.milanesi@unisi.it conducted to test for similarities and, if possible, to detect variations between individuals. By comparing morphometric analysis and molecular data we endeavoured to characterize a restricted group of cultivar.

\section{Materials and methods}

\subsection{Sampling and selection of archaeological material}

Ancient grape seeds obtained from archaeological excavations at Shahr-I Sokhta (fragments only; Figure 1A), Poggio Bacherina (Figure 1B), Miranduolo (Figure 1C), and Florence (Figure 1D) were documented with light micrographs. Seeds from Shahr-I Sokhta (Tosi 1978) were dated to $23^{\text {rd }}$ century $\mathrm{BC}$, seeds from Poggio Bacherina (Paolucci 1993) were dated to the second century BC, seeds from Miranduolo castle were dated between the late $10^{\text {th }}$ and early $11^{\text {th }}$ century BC (Nardini, Valenti 2003), seeds from Firenze (Cantini et al. 2007) were dated to the $13^{\text {th }}$ century BC. Samples were stored separately in sterile Falcon capsules and used, first, for the non-destructive quantitative morphometric analysis based on elliptic Fourier analysis (EFA), and then for destructive molecular DNA analysis. 


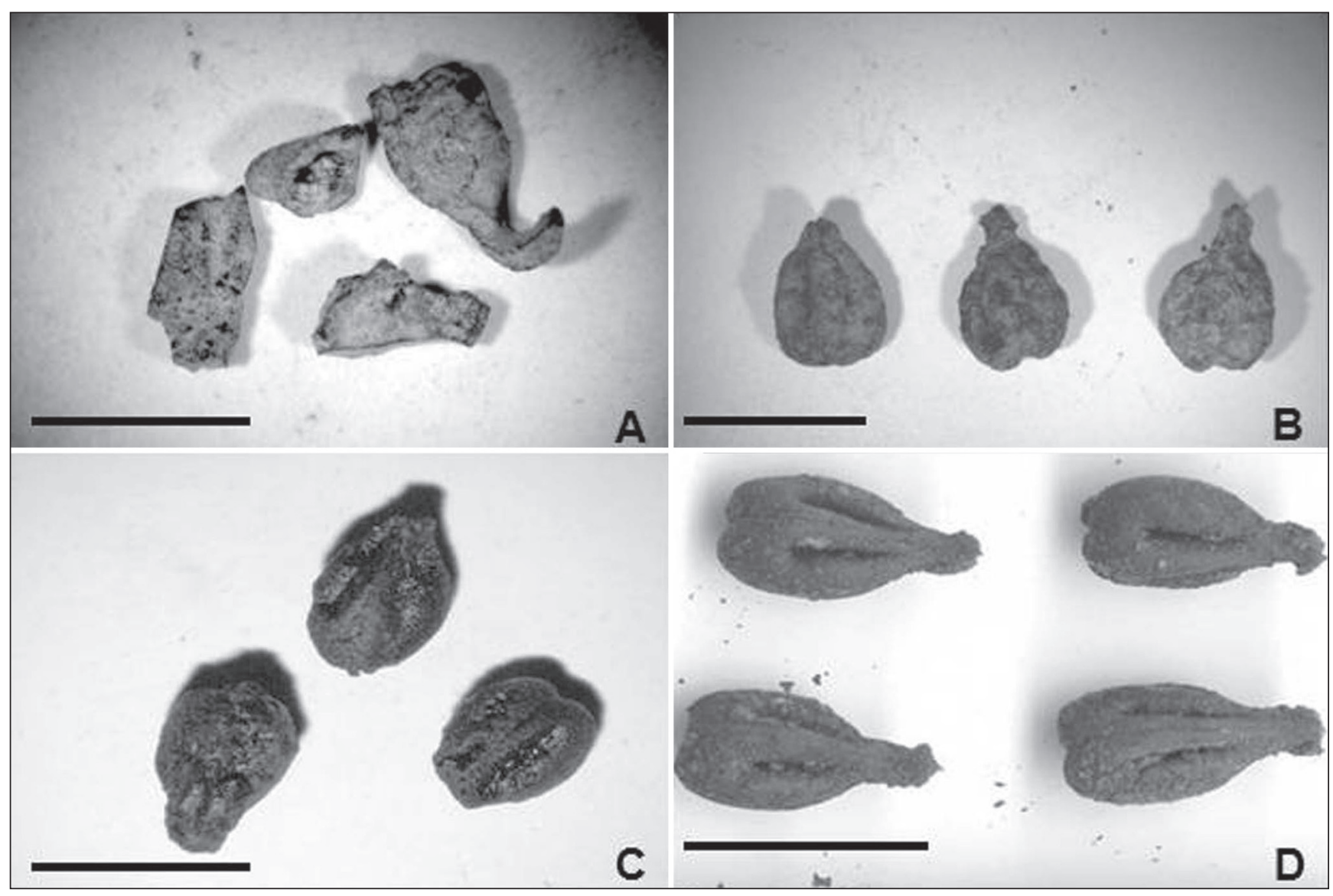

Figure 1. Light micrographs of archaeological grape seeds obtained from Shahr-I Sokhta (fragments only; Figure 1A), Poggio Bacherina (Figure 1B), Miranduolo (Figure 1C), and Florence (Figure 1D). (Magnifications Bar: $A=4 \mathrm{~cm}, \mathrm{~B}=5.5 \mathrm{~cm}, \mathrm{C}=5 \mathrm{~cm}, \mathrm{D}=7 \mathrm{~cm}$ ).

\subsection{Morphometric analysis}

The shape analysis of ancient grape seeds for each site, (Firenze, Miranduolo and Poggio Bacherina, three samples) was compared with fresh Tuscany cultivars from 11 varietals (Sangiovese Casciano, Sangiovese Montalcino, Cabernet Bossi, Merlot Bossi, Canaiolo Monti in Chianti, Canaiolo Montalbuccio, Trebbiano Montalbuccio, Trebbiano Tognazza, Malvasia Monti in Chianti, Albano Montalbuccio and Silevstris) and a total of 498 samples. The morphometric method was described in Milanesi et al. 2011 and Antonucci et al. 2012.

\subsection{DNA analysis}

Ancient seeds were quickly released from the matrix by $\mathrm{HCl}$ and HF treatment, which cleaned and removed organic matter (Milanesi et al. 2006), and subsequently exposed overnight to UV-light. Specimens were immediately processed for DNA extraction under controlled sterile conditions. Small pieces of archaeological and modern seeds were divided in two and processed separately for DNA extraction and PCR amplification under different sterile laminar-flow hoods. Genomic DNA was extracted using a method reported by Mulcahy et al. (1993). Seven different microsatellite markers (VVMD7, VVMD21, VVMD25, VVMD27, VVMD31, VVMD36, VVS2), generated by Bowers et al. (1999), were amplified. PCR amplification and amplicons detection were performed according to Masi et al. (2001). The amplified loci were cloned using the TOPO TA Clonig kit version F (INVITROGEN). Plasmids were extracted using the QIAGEN Plasmid Purification kit, and sequenced using the ALFexpress AutoRead Sequencing Kit, and analyzed on a polyacrylamide PAA gel run and the ALFexpressII semi-automated DNA sequencer. Post run data analysis was performed with the ALFwin sequence Analyzer 2.00. The generation of the consensus sequence and the pairwise sequence was carried out with DNAsys 2.10 software. The analysis was performed in order to observe VVMD7, VVMD21, VVMD25, VVMD27, VVMD31, VVMD36 and VVS2 at least three times.

\section{Results}

The frontal profile of endocarps was calculated on 495 fresh samples and 3 ancient seeds. The correct number of harmonics to use for computing the frontal profile of endocarps was calculated on all samples. The value selected (i.e. the first value exceeding $99.999 \%$ ) was 27 harmonics. The mean configuration (black line) and standard deviation (gray lines) for each cultivar are shown in Figure 2. It is 

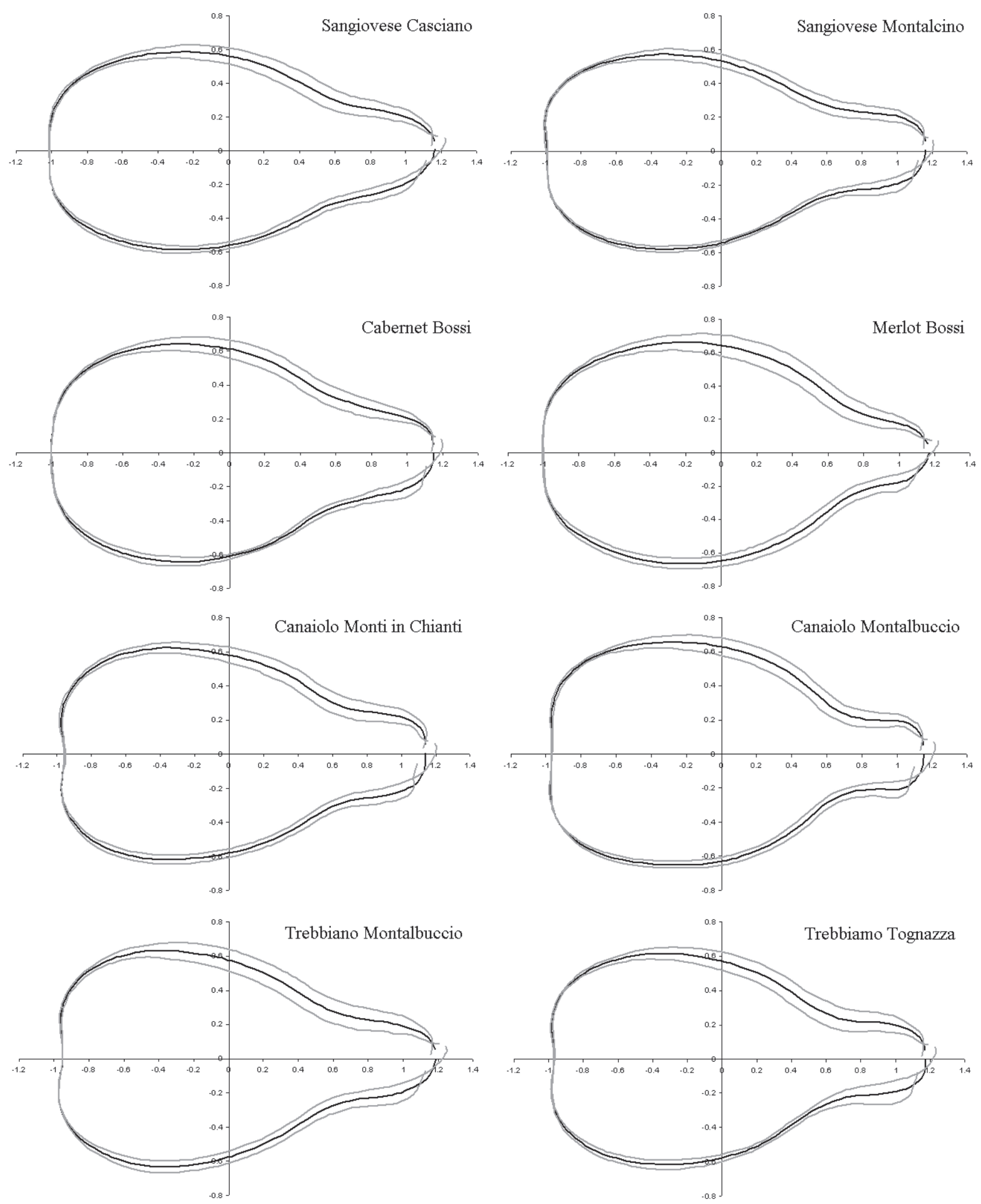

Figure 2. Shape morphometric analysis, frontal profile of fresh and archaeological endocarps were mean configuration (black line) and standard deviation (gray lines) for each cultivar are shown. It is possible to observe distinct shapes belonging to the different cultivars. 

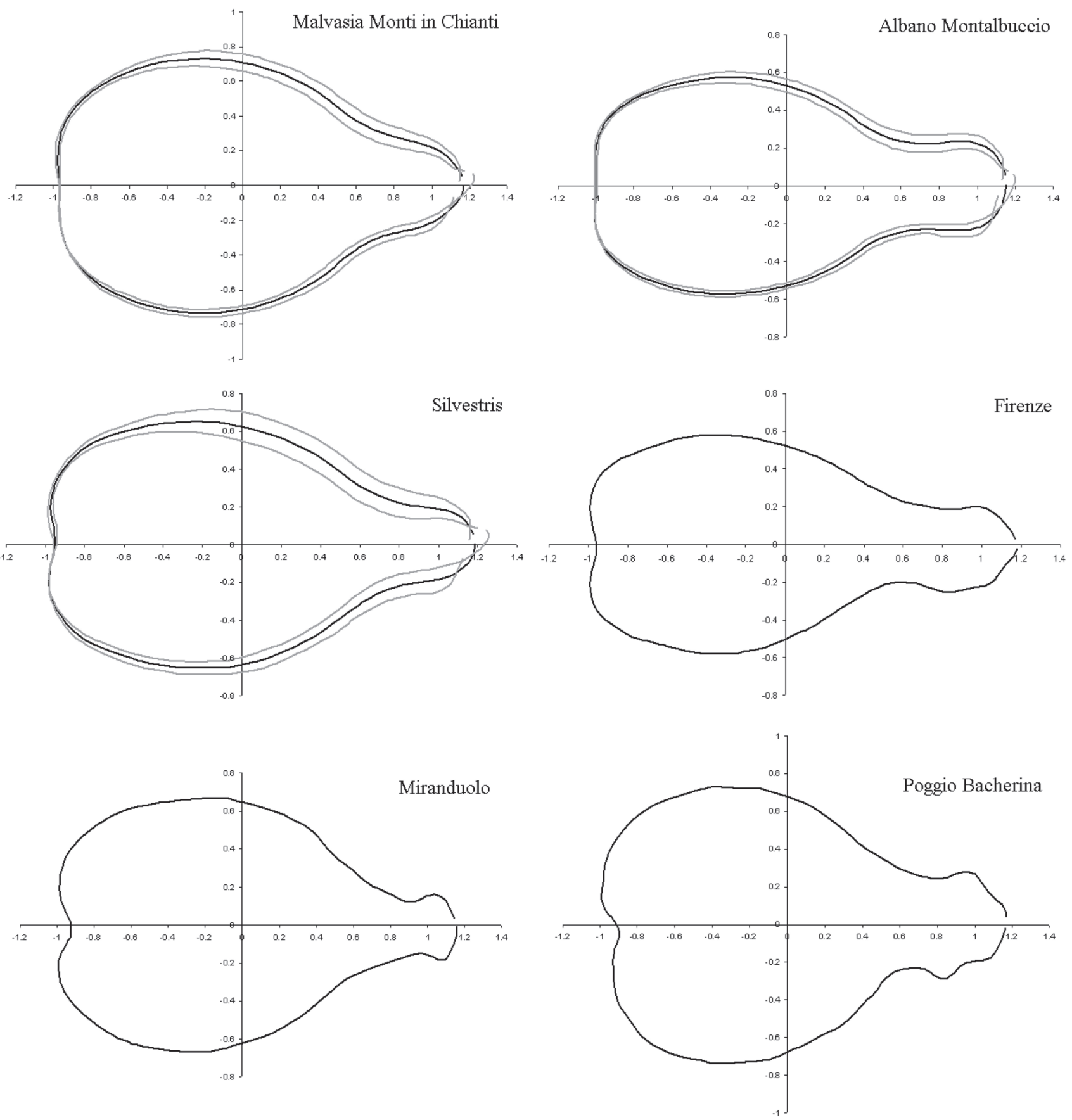

Figure 2. Shape morphometric analysis, frontal profile of fresh and archaeological endocarps were mean configuration (black line) and standard deviation (gray lines) for each cultivar are shown. It is possible to observe distinct shapes belonging to the different cultivars.

possible to observe distinct shapes belonging to the different cultivars. The cladogram, built on Euclidean distances between the mean shape configurations of each cultivar, calculated with the complete linkage algorithm using the EFA harmonic coefficients, appears in Figure 3. At a linkage distance of 0.08 , cluster analysis distinguished four groups. The first included Firenze, Albano di Montalbuccio and Sangiovese di Montalcino; the second Poggio Bacherina and Malvasia Monti in Chianti; the third Miranduolo, Silvestris, Canaiolo Montalbuccio and Merlot Bossi and finally the fourth included only living cultivars. The endocarp shapes of the cultivars of each group generally appeared to be similar.

All carpological samples were negative at the VVS2 nuclear microsatellite locus (Table 1). In particular, the genetic material of samples from Shahr-I Sokhta (Iranian archaeological seeds dated to $23^{\text {rd }}$ century BC) proved to be of good quality. The molecular data deposited in data banks showed homology below 1\% with 25 different modern cultivars. The loci VVMD27 and VVMD31 were not found in the samples from Florence. Analysis of the four alleles 


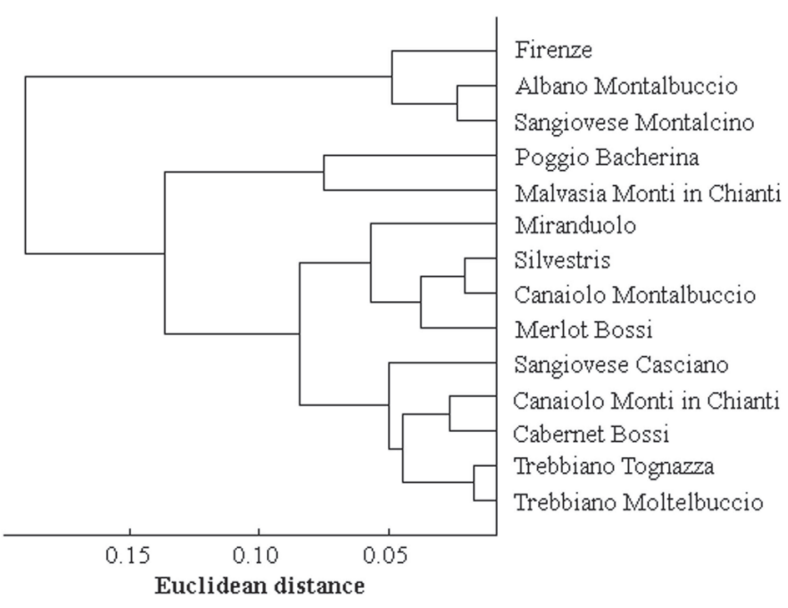

Figure 3. Cladrogram with Euclidean distances mean shape configurations of each cultivar. Cluster analysis distinguished four groups: first included Firenze, Albano di Montalbuccio, Sangiovese di Montalcino, second Poggio Bacherina, Malvasia Monti in chianti, third Miranduolo, Silvestris, Canaiolo Montalbuccio, Merlot Bossi and the fourth incuded only fresh cultivars.

obtained showed 7\% homology with the Sangiovese cultivar. Etruscan seeds from Poggio Bacherina and Medieval seeds from Miranduolo castle included in the analysis were negative at every microsatellite locus, confirming the observations obtained by microanalysis and cytochemical staining.

\section{Discussion}

Morphometric variability in contemporary cultivars reveals phenotypic divergence in groups of individuals diversified by climatic, ecological, historical and socio-cultural factors (Terral et al. 2004; Terral et al. 2010). For shape analysis of living seeds, the high number of samples tested (nearly
500), should be considered reliable, while the few ancient seeds (3), did not allow the determination of an average ideal shape, only a direct comparison of individual characteristics. Ancient seeds are rare and a database of living seeds can be useful for other future analysis. In addition, morphometric studies are non-invasive and considered ideal for rare and valuable archaebotanical remains. A way to partially solve this issue could be to borrow macro plant remains from museum collections.

In this analysis, DNA was found in specimens from prehistoric Iranian and Florence. Mineral substrates contribute to "entombing" (Eglinton, Logan 1991) or cementing subfossil cytoplasm and preventing oxidation. Samples from the Iranian archaeological site were also subject to osmotic dehydration by salinity that transferred water by formation of anaerobic systems (Hirayama et al. $1995)$ with DNA preservation. Seeds from Florence were stored in underground tunnels. Seeds from the Florence archaeological site were in a waterlogged context, were positive to DNA microsatellite amplifications. The liquid matrix of urban sediments probably formed barriers that maintained substrate humidity, isolating and reducing exogenous degeneration (Manen et al. 2003). Salt dehydrated and waterlogged archaeological seeds may be a good source of archaeobotanical DNA. In Poggio Bacherina, Etruscan seeds were in aerobic conditions that lead to mineralization, loss of preservation and/or insufficient genomic DNA. In Miranduolo Medieval castle, specimens were associated with anthropomorphic impacts; seeds were charred or collapsed, and suitable only for morphometric studies (Nardini, Valenti 2003).

The molecular results were compared with national and international contemporary cultivars in data banks (Sefc et al. 1998; Bowers et al. 1999; Vouillamoz et al. 2006) and we submitted the data obtained with the seven

Table 1. Summarized allele size obtained with seven microsatellite markers (VVMD7, VVMD21, VVMD25, VVMD27, VVMD31, VVMD36, VVS2) from archaeological grape seeds.

\begin{tabular}{|c|c|c|c|c|c|}
\hline Specimens seeds & 1. Shahr-1 Sokhta $0 \%$ & 2. Florence $7 \%$ Sangiovese & 3. Poggio Bacherina & 4. Miranduolo Castle & Laminar woods \\
\hline \multirow{2}{*}{ VVMD7 } & 238-244 BP & $245-253 \mathrm{BP}$ & - & - & 1 \\
\hline & 238-244 BP & $245-253 \mathrm{BP}$ & - & - & 2 \\
\hline \multirow{2}{*}{ VVMD21 } & 222-222 BP & $225-255 \mathrm{BP}$ & $228-228 \mathrm{BP}$ & - & 1 \\
\hline & 222-222 BP & $225-255 \mathrm{BP}$ & 228-228 BP & - & 2 \\
\hline \multirow{2}{*}{ VVMD25 } & 229-262 BP & 234-242 BP & 234-242 BP & - & 1 \\
\hline & 229-262 BP & 234-242 BP & 234-242 BP & - & 2 \\
\hline \multirow{2}{*}{ VVMD27 } & $228-228 \mathrm{BP}$ & - & - & - & 1 \\
\hline & 228-228 BP & - & - & - & 2 \\
\hline \multirow{2}{*}{ VVMD31 } & $226-226 \mathrm{BP}$ & - & - & - & 1 \\
\hline & 226-226 BP & - & - & - & 2 \\
\hline \multirow{2}{*}{ VVMD36 } & 229-230 BP & $255-255 \mathrm{BP}$ & - & - & 1 \\
\hline & 229-230 BP & $255-255 \mathrm{BP}$ & - & - & 2 \\
\hline \multirow{2}{*}{ VVS2 } & - & - & - & - & 1 \\
\hline & - & - & - & - & 2 \\
\hline
\end{tabular}


microsatellite markers (Vignani et al. 2008). We observed a degree of microsatellite oscillation that enabled us to exclude contamination (Cappellini et al. 2010).

\section{Conclusion}

Morphometric observations and genetic analysis could enable new comparisons of ancient profiles and contemporary cultivars, providing ideas for verifying hypotheses based on historical and other sources (Herodotus 484-425). In particular, the Firenze medieval archaeology seeds, show affinity with the Sangiovese and Albano while Miranduolo Etruscan seeds show affinity with Malvasia cultivar suggests trade in wine between the eastern Mediterranean and central Italy in Classical times, while certain typical varieties such as Malvasia white, Sangiovese and Albano plausibly became autochthonous varieties in the late Middle Ages, introduced into cenobite cloisters for limited production of wine and grapes by barbaric incursions.

\section{Acknowledgments}

We thank Giuliano Paolucci of the Archaeological and Civic Museum, Chianciano Terme and Lorenzo Costantini of the Oriental Art Institute, Rome for providing Iranian materials and Ariano Buracchi for selecting archaeological and lives grape seeds.

\section{References}

ANTONUCCI, F., COSTA, C., PAllottino, F., PAGlia, G., RIMATORI, V., De GIORGIO, D., MENESATTI, P. 2012: Quantitative method for shape description of almond cultivars (Prunus amygdalus Batsch). In press by Food and Bioprocess Technology.

BLATTER, R. H. E., JACOMET, S., SCHUMBAUM. A. 2002: Little evidence for the preservations of a single copy gene in charred archaeological wheat. Ancient Biomolecules 4, 55-77.

BOWERS, J.E., DANGL, G.S., MEREDITH, C.P. 1999: Development and characterization of additional microsatellite DNA marker for grape. American Journal of Enology and viticulture 50, 243-246.

CANTINI, F., CIANFERONI, C., FRANCOVICH, R., SCAMPOLI, E. 2007: Firenze prima degli Uffizi. Lo scavo di via de' Castellani: contributi per un'archeologia tra tardo antico ed età moderna. All'insegna del Giglio, Firenze.

CAPPELLINI, E., THOMAS, M., GILBERT, P., GENNA, F., FIORENTINO, G., HALL, A., THOMAS-OATES J., ASHTON, P.D., ASHFORD D. A., ARTHUR, P., CAMPOS, P.F., KOOL, J., WILLERSLEV, E., COLLINS, M. J. 2010: A multidisciplinary study of archaeological grape seeds. Naturwissenschaften 97, 205-217.

EGLINTON, G., LOGAN, G.A. 1991: Molecular preservation, Philosophical Transactions of the Royal Society of London. B333, 315-328.

HERODOTUS of HALICARNASSUS, 484-425 B.C. 2012: The Histories, nine manuscript books, available online, (http://classics.mit.edu/ Herodotus/history.html).

HIRAYAMA, T., OHTO, C., MIZOGUCHI, T., SHINOZAKI, K., 1995: A gene encoding a phosphatidylinositol-specific phospholipase $\mathrm{C}$ induced by dehydration and salt stress in Arabidopsis thaliana. Proceedings of the National Academy of Science USA, 92, 3903-3907.
MANEN, J.F., BOUBY, L., DALNOBY, O., MARINVAL, P., TURGAY, M., SCHLUMBAUM, A. 2003: Microsatellites from archaeological Vitis vinifera seeds allow a tentative assignment of the geographical origin of ancient cultivars. Journal of Archaeological Science 30, 721-729.

MANGAFA, M., KOTSAKIS, K. 1996: New method for the identification of wild and cultivated charred grape seeds. Journal of Archaeological Science 23, 409-418.

MASI, E., VIGNANI, R., DI GIOVANNANTUONO, A., MANCUSO, S., BOSELLI, M. 2001: Ampelographic and cultural characterisations of the Casavecchia variety. Horticultual Science 15, 47-55.

MENESATTI, P., COSTA, C., PAGLIA, G., PALLOTTINO, F., D’ANDREA, S., RIMATORI, V., AGUZZI, J. 2008: Shape-based methodology for multivariate discrimination among Italian Hazelnus cultivars. Biosystem Engineering 101/4, 417-424.

MILANESI, C., VIGNANI, R., CIAMPOLINI, F., FALERI, C., CATTANI, L., MORONI, A., ARRIGHI, S., SCALI, M., TIBERI, P., SENSI, E., WANG, W., CRESTI, M. 2006: Ultrastructure and DNA sequence analysis of single Concentricystis cells from Alta Val Tiberina Holocene sediment. Journal of Archaeological Science 33, 1081-1087.

MILANESI, C., SORBI, A., PAOLUCCI, E., ANTONUCCI, F., MENESATTI, P., COSTA, C., PALlOTTINO, F., ViGNANI, R., CIMATO, A., CIACCI, A., CRESTI, M. 2011: Pomology observations, morphometric analysis, ultrastructural study and allelic profiles of "olivastra Seggianese" endocarps from ancient olive trees (Olea europaea L.). Comptes Rendus Biologie 334, 39-49.

MULCAHY, D.L., CRESTI, M., SANSOVINI, S., DOUGLAS, G.C., LINSKENS, H.F., BERGAMINI_MULCAHY, G., VIGNANI, R., PANCALDI, M. 1993: The use of random amplified polymorphic DNAs to fingerprint apple genotypes. Horticultural Science 54, 89-96.

NARDINI, A., VALENTI, M. 2003: The Miranduolo Castle, Chiusdino, Siena. In: Fiorillo, R., Perduto, P., 2-5 October III Medieval Archaeology Congress, Salerno, 488-495.

PAOLUCCI, G. 1993: L'insediamento tardo etrusco di Poggio Bacherina a Chianciano Terme: La civiltà di Chiusi e del suo territorio. In: Atti XVII Convegno di Studi Etruschi e Italici (Atti Convegno Chianciano Terme 1989), Firenze.

SEFC, K.M., STEINKELLNER, H., GLOSSL, J., KAMPFER, S., REGNER, F. 1998: Reconstruction of a grapevine pedigree by microsatellite analysis. Theoretical and applied genetics 97, 227-231.

SEFC, K.M., LOPES, M.S., LEFORT, F., BOTTA, R., ROUBELAKISANGELAKIS, K.A., IBANES, J., PEJIC, I., WAGNER, H.W., GLOSSL, J., STEINKELLNER, H. 2000: Microsatellite variability in grapevine cultivars from different European region and evaluation of assignment testing toaccess the geographic origin of cultivars. Theoretical and Applied Genetics 100, 498-505.

TERRAL, J.F., ALONSO, N., BUXO', R., CAPDEVILA, I., CHATTI, N., FABRE, L., FIORENTINO, G., MARINVAL, P., PEREZ-JARDA, G., PRADAT, B., ROVIRA, N., ALIBERT, P. 2004: Historical biogeography of olive domestication (Olea europaea L.) as revealed by geometrical morphometry applied to biological and archaeological material. Journal of Biogeography 31, 63-77.

TERRAL, J. F., TABARD, E., BOUBY, L., IVORRA, S., PASTOR, T., FIGUEIRAL, I., PICQ, S., CHEVANCE, J. B., JUNG, C., FABRE, L., TARDY, C., COMPAN, M., BACILIERI, R., LACOMBE, T., THIS, P. 2010: Evolution and history of grapevine (Vitis vinifera) under domestication: new morphometric perspectives to understand seed domestication syndrome and reveal origins of ancient European cultivars. Annals of Botany 105, 443-445.

TOSI, M. 1978: Ricerche archeologiche sulla protostoria del Sistan: Un Decennio di Ricerche Archeologiche. Quaderni de 'La Ricerca Scientifica' 100, Roma CNR.

VIGNANI, R., MASI, E., SCALI, M., MILANESI, C., SCALABRELLI, G., WANG, W., SENSI, E., PAOLUCCI, E., PERCORO, G. M., CRESTI, M. 2008: A critical evaluation of SSRs analysis applied to Tuscan grape (Vitis vinifera L.) germplasm. Advances Horticulture Science 22, 33-37.

VOUILLAMOZ, J. F., SCHNEIDER, A., GRANDO, M. S. 2006: Microsatellite analysis of Alpine grape cultivars (Vitis vinifera L.): alleged descendants of Pliny the Elder's raetica are genetically related. Genetic Resources and Crop Evolution 54, 1095-1104. 